\title{
PRZEDMOWA DO WYDANIA 14
}

Wydanie czternaste zostało na nowo opracowane i poszerzone. Dokonano licznych zmian w wielu częściach książki, aby sprostać nowym zadaniom dzisiejszego stanu wiedzy położniczej. Niektóre rozdziały zostały prawie zupełnie na nowo napisane (okres łożyskowy, wstrząs endotoksyczny, zaburzenia krzepliwości krwi w położnictwie, późna gestoza, profilaktyka konfliktu w zakresie czynnika Rh). Rozdzial "Choroba hemolityczna noworodków” opracowała moja żona, dr J. Pschyrembel.

Do wydania czternastego dołączono dwa nowe rozdziały: „Propedeutyka i klinika diagnostyki perinatalnej”, opracowany przez J. Bretschera z Zürichư i „Ultradźwięki w położnictwie", opracowany przez D. Hofmanna z Münsteru.

Metodyka medycyny perinatalnej, usiłowanie dotarcia do płodu bezpośrednio i pośrednio wymagają wręcz olbrzymiego zaplecza, jeśli chodzi o wyposażenie w aparaturę. Za pomocą specjalnej aparatury wykonując chemiczne badanie krwi potrafimy dzisiaj uchwycić stany niedotlenienia i kwasicy, które mogą być spowodowane przez różnorodne czynniki, możemy też rozpoznać zagrażające stany niewydolności łożyska (na skutek niedostatecznego dowozu substancji odżywczych i zaburzeń w oddychaniu). Smiertelność okołoporodowa wykazuje w nowszych czasach tendencje spadkowe. Pilnym zadaniem medycyny perinatalnej jest jednak dzisiaj nie tylko dążenie do dalszego zmniejszenia śmiertelności okołoporodowej, lecz o wiele bardziej dążenie do zapobiegania zachorowalności okresu poporodowego, szczególnie uszkodzeniom mózgu.

Z odpowiednimi uzupełnieniami odnośnie do podstaw fizjopatologii i diagnostyki w zakresie sprawdzonych dzisiaj metod podręcznik ten przedstawia najnowszy stan wiedzy.

W. PSCHYREMBEL 